\title{
Effect of smoking habits and timolol treatment on mortality and reinfarction in patients surviving acute myocardial infarction
}

\author{
PER K RØNNEVIK, TORSTEIN GUNDERSEN, A M ABRAHAMSEN \\ From the Medical Department, Section of Cardiology, Central Hospital, Rogaland, Stavanger, Norway
}

SUMmary The Norwegian Multicenter Group Study noted the effect of smoking habits before and after myocardial infarction and their relation to mortality and reinfarction rate after treatment with timolol in patients surviving acute myocardial infarction. The mean follow up period was $17 \cdot 3$ (range 12-33) months. No relation was found between initial smoking habits and risk category after infarction or between initial smoking habits and later outcome. At the time of their first infarct smokers were seven years younger than non-smokers. One month after infarction nearly $60 \%$ of the smokers had stopped smoking completely. A significantly lower incidence of early cardiac death and lower total mortality was found in patients treated with timolol in both those who continued smoking and in the combined non-smoking groups and a significantly lower reinfarction rate among non-smokers. Cessation of smoking alone was associated with a reduced reinfarction rate by $45 \%$ but a non-significant reduction in mortality by $26 \%$.

It is concluded that treatment with timolol and cessation of smoking have an additive effect in reducing mortality and reinfarction rate after myocardial infarction.

The use of beta-receptor blockers after acute myocardial infarction has been found to reduce overall mortality. ${ }^{1-3}$ The effect of smoking habits on mortality and reinfarction in these patients has, however, not been reported. In this report we present a detailed analysis of the Norwegian multicenter timolol trial ${ }^{1}$ with respect to smoking habits before and after infarction and their correlation with prognosis.

\section{Patients and methods}

A detailed description of the study design, eligibility criteria, follow up procedures, end point evaluation, data handling, and statistical methods has been published. ${ }^{1}$ Treatment with timolol $10 \mathrm{mg}$ twice daily was started 7-28 days after the onset of symptoms. The patients were stratified to three risk groups: group 1 consisted of patients with recurrent myocardial infarction with or without conditions for possible high risk; group 2 consisted of patients with a first myocardial

Requests for reprints to Dr Per K Ronnevik, Medical Department, Haukeland Hospital, N-5016 Haukeland Sykehus, Norway.

Accepted for publication 2 April 1985 infarction and one or more of five high risk conditions'; and group 3 consisted of patients not at high risk (the remaining patients).

\section{STUDY POPULATION}

A total of 1884 patients were included in the study. Of these, 945 patients were randomised to treatment with timolol (752 men and 193 women), and 939 to treatment with placebo (732 men and 207 women). The patients were followed for 12-33 months (mean 17.3 months). Smokers were given individual advice on the relation of continued smoking and their heart disease and were encouraged to stop. Smoking habits were assessed by an interview at each visit.

Smoking data for the $12.2 \%$ of the patients with acute myocardial infarction who died before inclusion or for patients who were excluded from entry for other reasons were not recorded.

\section{CLASSIFICATION}

Patients were classified as non-smokers if they had never smoked, as ex-smokers if they had stopped smoking more than one month before the infarction, as new ex-smokers if they had stopped smoking after 
Table 1 Initial smoking habits in patients surviving myocardial infarction according to risk group. Figures are mumbers (\%) of parients

\begin{tabular}{|c|c|c|c|c|}
\hline & $\begin{array}{l}\text { Group } 1 \\
(n=352)\end{array}$ & $\begin{array}{l}\text { Group } 2 \\
(n=1091)\end{array}$ & $\begin{array}{l}\text { Group } 3 \\
(n=441)\end{array}$ & $\begin{array}{l}\text { Groups combined } \\
(n=1884)\end{array}$ \\
\hline $\begin{array}{l}\text { Smokers } \\
\text { Ex-smokers } \\
\text { Non-smokers } \\
\text { Smokers (grams of tobacco } \\
\text { smoked): }\end{array}$ & $\begin{array}{r}151(42 \cdot 9) \\
131(37 \cdot 2) \\
70(19 \cdot 9)\end{array}$ & $\begin{array}{l}613(56 \cdot 2) \\
235(21 \cdot 5) \\
243(22 \cdot 3)\end{array}$ & $\begin{array}{r}241(54 \cdot 7) \\
106(24 \cdot 0) \\
94(21 \cdot 3)\end{array}$ & $\begin{array}{r}1005(53 \cdot 3) \\
472(25 \cdot 1) \\
407(21 \cdot 6)\end{array}$ \\
\hline $\begin{array}{l}1-4 \\
5-14 \\
15-24 \\
>25 \\
\text { Duration of smoking (years): }\end{array}$ & $\begin{array}{l}29(19.2) \\
83(55.0) \\
27(17.9) \\
12(7.9)\end{array}$ & $\begin{array}{c}50(8.2) \\
359(58 \cdot 5) \\
147(24.0) \\
57(9 \cdot 3)\end{array}$ & $\begin{array}{l}27(11 \cdot 2) \\
142(58.9) \\
60(24.9) \\
12(5.0)\end{array}$ & $\begin{array}{c}106(10 \cdot 5) \\
584(58 \cdot 1) \\
234(23 \cdot 3) \\
81(8 \cdot 1)\end{array}$ \\
\hline $\begin{array}{l}0-9 \\
10-24 \\
25-39 \\
>40\end{array}$ & $\begin{array}{l}-14(9.3) \\
45(29.8) \\
92(60.9)\end{array}$ & $\begin{array}{c}5(0.8) \\
78(12 \cdot 7) \\
243(39.7) \\
287(46.8)\end{array}$ & $\begin{array}{c}1(0.4) \\
26(10-8) \\
104(43 \cdot 2) \\
110(45 \cdot 6)\end{array}$ & $\begin{array}{c}6(0-6) \\
118(11 \cdot 7) \\
392(39 \cdot 0) \\
489(48 \cdot 7)\end{array}$ \\
\hline
\end{tabular}

the infarction for one month or more, and as smokers if they continued smoking. One cigarette was defined as $1 \mathrm{~g}$ of tobacco, one cigarillo as $\mathbf{2} \mathbf{g}$, and one cigar as $5 \mathrm{~g}$.

\section{OUTCOME}

Early cardiac death was defined as death occurring without previous symptoms or within 24 hours of the onset of new symptoms of heart disease.

\section{Results}

\section{SMOKING HABITS AND INFARCT}

CHARACTERISTICS

Table 1 shows the smoking habits in the three risk groups of the patients surviving the acute stage of the myocardial infarction. One thousand and five patients (53.3\%) were smokers before the infarct $(59.4 \%$ of men and $31 \%$ of women), 472 (25\%) ex-smokers, and $407(21.6 \%)$ non-smokers. Of the smokers, 849 (84.5\%) smoked cigarettes, nine ( $0.9 \%)$ cigarillos or cigars, and $147(14.6 \%)$ pipes. Of the smokers, 935 (93\%) inhaled and $70(7 \%)$ did not. The non-inhalers and pipe smokers were equally distributed among the risk groups, and because of the small number they are included in the smoker group in this analysis.

Several hundred comparisons of patient characteristics within and among risk groups were made. The differences between the treatment groups tended to be small, and when the differences are adjusted for by the Cox regression model they did not influence the life table analyses.

The total mortality in the placebo treated patients was highest in risk group $1(17.8 \%)$ followed by risk group $2(13.6 \%)$, and lowest in risk group $3(5 \cdot 4 \%)$.

The distribution of smokers, ex-smokers, and non-smokers was similar in risk groups 2 and 3 , as was the amount of tobacco smoked and the duration of smoking. Of the smokers, $59 \%$ smoked $5-14 \mathrm{~g}$ of tobacco daily, and $9.3 \%$ in risk group 2 and $5.0 \%$ in risk group 3 (not significant) smoked $>25 \mathrm{~g}$. Mean duration for smoking was 35.4 years (37.2 years for men and 27.4 years for women). Very few patients had smoked for less than 10 years (12 patients).

In risk group 1 (recurrent infarction) there were significantly fewer smokers $(p<0.01)$ and significantly more ex-smokers $(p<0.001)$ than in the other risk groups. Smokers with a recurrent infarction had a lower tobacco consumption than smokers with a first myocardial infarction. Of the smokers in risk group 2, $8.2 \%$ had a low tobacco consumption of $1-4 \mathrm{~g}$ daily compared with $19.2 \%$ of smokers with a recurrent infarction $(p<0.001)$. Twenty four per cent of smokers in risk group 2 compared with $17.9 \%$ in risk group 1 ( $p<0.001)$ smoked 15-24 g daily. The ex-smokers (risk groups combined) had stopped smoking for a mean of 11.1 years before inclusion in the study and had been smoking for a mean of 28.4 years before they stopped.

Smoking habits in patients surviving the acute phase of a first myocardial infarction therefore seem not to be correlated with high or low risk categories after myocardial infarction. Nevertheless, subjects with recurrent infarction have a lower tobacco consumption than those with a first myocardial infarction. Likewise we found no correlation between smoking habits at the time of infarction and later death.

Age at inclusion in the study was correlated with smoking status. Smokers who survived their first complicated infarct (risk group 2) were 6.8 years younger than non-smokers (58.4 years vs 65.2 years) and four years younger than ex-smokers.

INITIAL SMOKING HABITS AND OUTCOME

Table 2 shows the distribution, according to initial smoking habit, of the number of all deaths, early cardiac deaths, and non-fatal reinfarctions occurring dur- 
Table 2 Frequency distribution of deaths and reinfarctions by initial smoking status in patients treated with placebo $(P)$ or timolol (T). Figures are mombers (\%) of patients

\begin{tabular}{|c|c|c|c|c|c|c|c|c|}
\hline \multirow[t]{2}{*}{ Category } & \multicolumn{2}{|l|}{ Smoker } & \multicolumn{2}{|l|}{ Ex-smoker } & \multicolumn{2}{|l|}{ Non-smoker } & \multicolumn{2}{|c|}{ All cambined } \\
\hline & $P$ & $T$ & $P$ & $T$ & $P$ & $T$ & $P$ & $T$ \\
\hline $\begin{array}{l}\text { Total No of patients } \\
\text { Deaths during treatment or within } \\
28 \text { days of withdrawal: }\end{array}$ & 493 & 512 & 234 & 238 & 212 & 195 & 939 & 945 \\
\hline $\begin{array}{l}\text { Early cardiac death } \\
\text { All deaths }\end{array}$ & $\begin{array}{l}50(10.1) \\
58(11.8)\end{array}$ & $\begin{array}{l}28(5 \cdot 5)^{\star} \\
37(7 \cdot 2)^{\star}\end{array}$ & $\begin{array}{l}24(10.7) \\
34(14.5)\end{array}$ & $\begin{array}{l}9(3.8)^{\star \star} \\
13(5.5)^{\star \star}\end{array}$ & $\begin{array}{l}20(9.4) \\
25(11 \cdot 8)\end{array}$ & $\begin{array}{l}10(5 \cdot 1) \\
17(8 \cdot 7)\end{array}$ & $\begin{array}{r}95(10.1) \\
117(12 \cdot 5)\end{array}$ & $\begin{array}{l}47(5 \cdot 0)^{\star \star \star} \\
67(7 \cdot 1)^{\star \star \star}\end{array}$ \\
\hline $\begin{array}{l}\text { Non-fatal reinfarctions during treatment } \\
\text { or within } 28 \text { days of withdrawal }\end{array}$ & $58(11 \cdot 8)$ & $48(9.4)$ & $38(16 \cdot 2)$ & $19(8 \cdot 0)^{\star \star}$ & $29(13 \cdot 7)$ & $13(6.7)^{\star}$ & $141(15.0)$ & $88(9.3)^{\star \star \star}$ \\
\hline
\end{tabular}

${ }^{\star} \mathrm{p}<0.05 ;{ }^{\star \star} \mathrm{p}<0.01 ;{ }^{\star \star \star} \mathrm{p}<0.001$.

ing treatment or within 28 days of withdrawal from the study. The total number of deaths were 117 in the placebo group and 67 in the timolol group $(p<0.001)$, a reduction of $43 \%$. The number of early cardiac deaths was 95 in the placebo group and 47 in the timolol group $(p<0.001)$. Overall mortality and the incidence of early cardiac death were significantly reduced in the ex-smokers $(p<0.01)$ and initial smokers $(p<0.05)$ treated with timolol. The reduction in the number of early cardiac deaths and of all deaths in the non-smoker group was not significant. We found no difference in the incidence of early death, all deaths, or reinfarction between timolol treated smokers and timolol treated ex-smokers or between placebo-treated smokers and placebo-treated exsmokers.

The number of initial reinfarctions was 141 in the placebo group and 88 in the timolol group $(p<0.001)$, a reduction of $38 \%$. The incidence of initial reinfarctions was significantly reduced in the timolol treated ex-smokers $(p<0.01)$ and in non-smokers $(p<0.05)$. The reduction in reinfarction rate among initial smokers treated with timolol or placebo was not significant.

\section{EFFECT OF CHANGING SMOKING HABITS}

Figure 1 shows the change in smoking habits during the first year of follow up in the two treatment groups. One month after the infarction the proportion of smokers had fallen from $52.5 \%$ to $21 \%$ in the placebo group, and from $54.7 \%$ to $22.7 \%$ in the timolol group; $58-60 \%$ of the smokers had therefore stopped smoking completely. In this analysis we did not take into account the amount of tobacco smoked. The smoking pattern remained remarkably constant during follow up. A non-significant increase from $22.7 \%$ one month after inclusion to $25.9 \%$ after one year was found in the number of smokers in the timolol group. There was little crossover between the smoking groups. Only one initial non-smoker became a smoker later, and 16 ex-smokers started smoking again during the first year. Changes in smoking habits were recorded one month after the change had occurred. One hundred and ninety nine patients with a follow up of less than one month because of withdrawals (58 in placebo group, 81 in timolol group) or death (37 in placebo group, 23 in timolol group) were excluded from this analysis. A total of 1685 patients continued follow up, and Table 3 and Fig. 2 show the mortality and reinfarction rates.

Overall mortality was highest in placebo treated smokers (11-3\%). Among those who continued smoking we found a significantly reduced incidence of early cardiac death in the timolol group compared with the placebo group (15 vs four, $p<0.05$ ), a reduction of $75 \%$, and of all deaths (20 vs nine, $p<0.05$ ). In the non-smoking groups combined the reduction in incidence of early cardiac death was $47 \%$ ( 51 vs 26 , $\mathrm{p}<0.01)$ and of all deaths $40 \%$ (60 vs $35, \mathrm{p}<0.05)$ in the timolol group compared with the placebo group. Among ex-smokers the reduction in the incidence of early cardiac death in the timolol group compared with the placebo group was $63 \%$ ( 19 es seven $p<0.05$ ) whereas that in the incidence of all deaths was not significant. Treatment with timolol of those who stopped smoking (new ex-smokers) was associated with a reduction in total mortality of $39 \%$ (not significant) and early cardiac death by $39 \%$ (not significant). In the placebo treated patients cessation of smoking was associated with a reduction in total mortality of $26 \%$ (not significant).

We found a significant reduction in the incidence of initial reinfarctions in ex-smokers ( 27 vs 13, $\mathrm{p}<0.05$ ) and in all non-smokers combined $(73$ vs $47, \mathrm{p}<0.05$ ) in patients treated with timolol. The reduction in incidence of reinfarctions among smokers was not significant (Table 3, Fig. 2b). Nevertheless, cessation of smoking reduced the reinfarction rate by $45 \%$ $(p<0.05)$ in placebo treated patients. Twenty six (14.7\%) of 177 patients who continued smoking and $22(8 \%)$ of 276 who ceased smoking had non-fatal reinfarctions during the study. In the new ex-smoker group the reinfarction rate was the same $(8 \%)$ with or without timolol treatment. A placebo treated continued smoker had a more than twofold reinfarction rate compared with a timolol treated ex-smoker. 

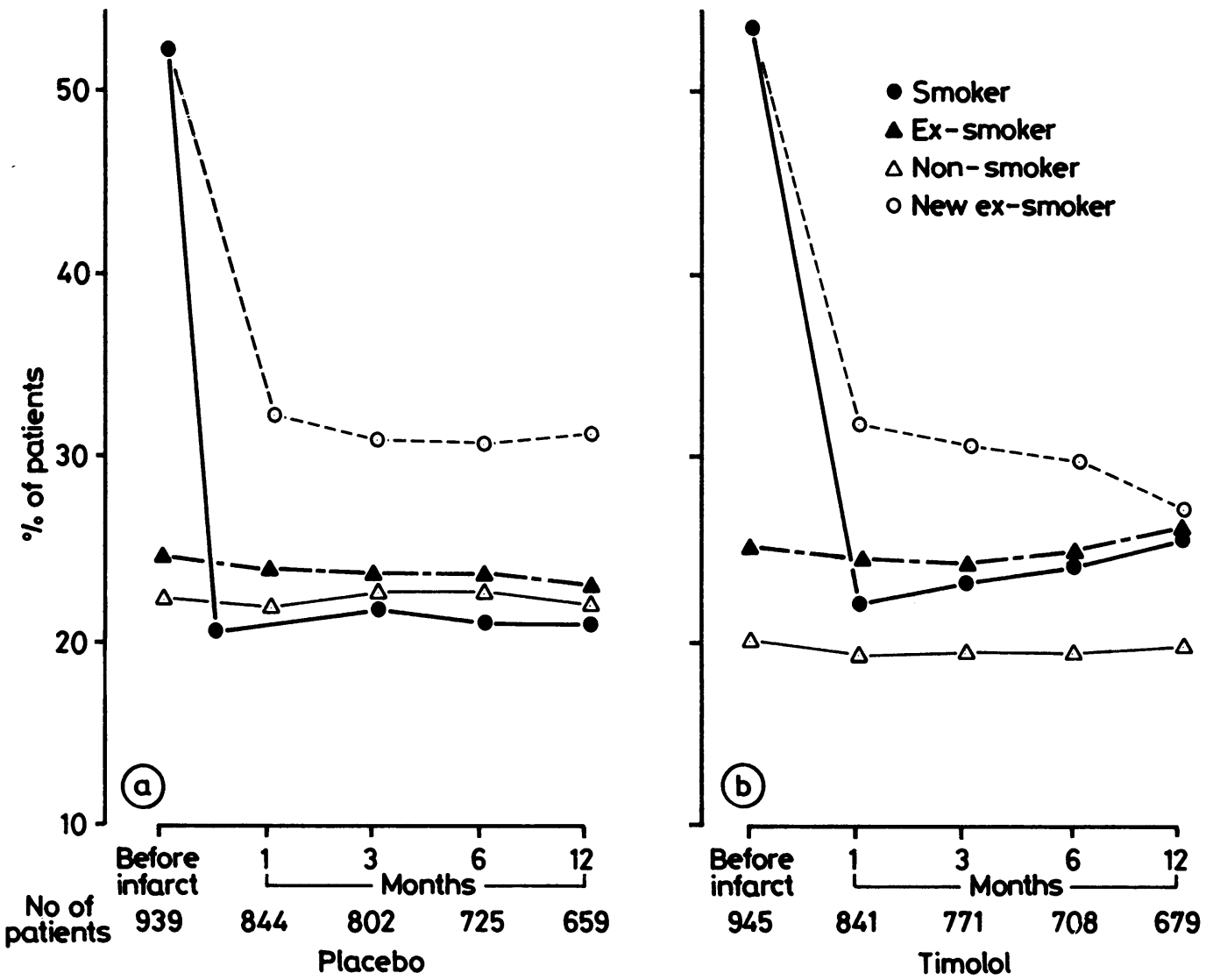

Fig. 1 Smoking habits dering study in combined risk groups, treated with (a) placebo or (b) timolol.

\section{Discussion}

Of the men and women alive seven days after acute myocardial infarction and included in this study, $59.4 \%$ and $31 \%$ respectively were smokers. Of the total population of Norway at the time the study took place, $44 \%$ of men and $31 \%$ of women aged 16 to 74 years were reported to be smokers. ${ }^{4}$ The higher pro- portion of smokers in the study population probably reflects the fact that smoking is a primary risk factor for coronary heart disease, although we did not record smoking data for the $48 \%$ of patients excluded out of the 3647 patients with myocardial infarction initially screened. Hospital mortality due to acute myocardial infarction has been reported to be higher in smokers than in non-smokers, ${ }^{5}$ decreasing the proportion of

able 3 Frequency distribution of deaths and reinfarctions fram second month of follow up. Figures are rambers (\%) of patients

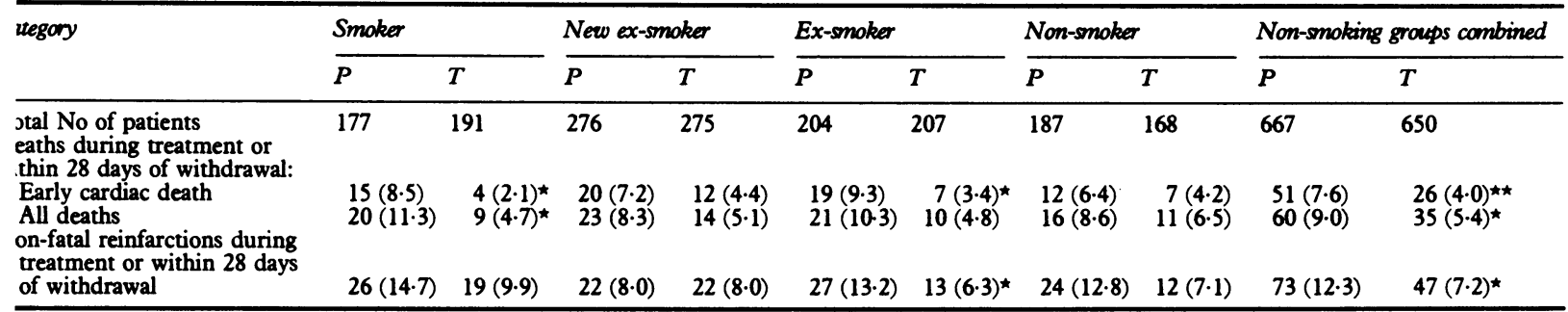

$<0.05 ;{ }^{\star} \mathrm{p}<0.01$. 

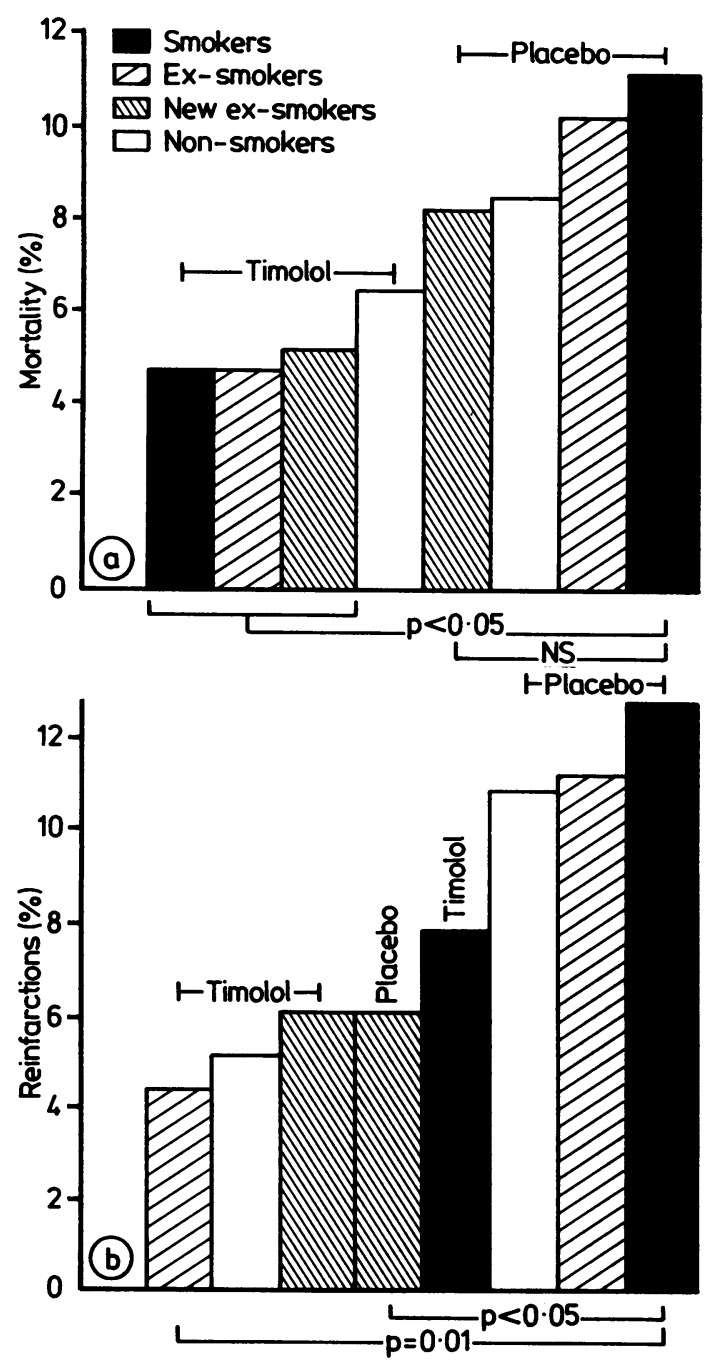

Fig. 2 (a) Total mortality and (b) reinfarction rate according to smoking habit in patients treated with timolol or placebo.

smokers among survivors of myocardial infarction. The association of smoking with the development of coronary heart disease is well known. ${ }^{5-14}$ The risk of coronary heart disease increases with the increasing amount smoked irrespective of other known risk factors-for example, hypertension or increased plasma cholesterol concentrations. ${ }^{15}$ The risk of coronary heart disease is unrelated to the years of exposure to smoking, ${ }^{6}$ which suggests an immediate and noncumulative effect of tobacco smoking on the incidence of coronary heart disease.

In the present study the classification of patients into three risk groups probably correctly reflects the extent of myocardial damage. ${ }^{1}$ As expected, the mor- tality rate was highest in the patients with a recurrent infarction and lowest in patients with a first uncomplicated myocardial infarction. We did not find any significant differences in initial smoking patterns in patients surviving a first myocardial infarction with or without complications (risk groups 2 and 3). In risk groups 2 and $3,56 \cdot 2 \%$ and $54.7 \%$ respectively were initial smokers. The smoking pattern with regard to amount smoked or the duration of smoking was not different, although $9.3 \%$ of smokers in risk group 2 smoked $>25$ cigarettes a day compared with $5 \%$ in risk group 3. The proportion of smokers was smaller in patients with a recurrent infarction than in patients with a first myocardial infarction, probably reflecting the effect of smoking counselling after their previous myocardial infarction.

Smoking, together with serum lipid concentrations and blood pressure, is associated with the highest risk for coronary heart disease. Prospective epidemiological investigations have reported that smoking shows higher relative risk ratios among younger persons than older cohorts. ${ }^{11}$ The strong relation between smoking habits and age of survivors after acute myocardial infarction in this study may partly be due to more smokers of advanced age dying in the acute stage.

Several intervention studies have assessed the effect of stopping smoking in healthy persons. No significant effect of stopping smoking on death from coronary heart disease was reported by Rose and Hamilton and Rose et al. 1617 The Multiple Risk Factor Intervention Trial ${ }^{18}$ and the World Health Organisation European Collaborative Group ${ }^{19}$ reported a significant reduction in coronary heart disease and mortality when risk factors such as hypertension, smoking, high plasma cholesterol concentrations, and weight were reduced. A report from the Framingham Study showed that men who gave up smoking reduced their risk of coronary heart disease by a half. "1 Nevertheless, those subjects over 65 years derived no such benefit from giving up smoking. The Oslo Study Group reported a significant reduction in the incidence of myocardial infarction and sudden cardiac death when high serum cholesterol concentrations were controlled and smoking was reduced.20

Cessation of smoking after myocardial infarction is associated with a significant reduction in cardiovascular mortality. ${ }^{21-28}$ A $61 \%$ reduction in the mortality rate over a six year period was reported from the Framingham Study, ${ }^{29}$ and a $55 \%$ lower 13 year mortality in those who stopped smoking after an episode of unstable angina or myocardial infarction compared with those who continued smoking was reported by Daly et al.$^{30}$ In all risk groups combined we found a highly significant reduction in total mortality and the incidence of early deaths in patients treated with 
timolol. Although the observed reduction in total mortality of $26 \%$ in those who stopped smoking (and treated with placebo) did not reach statistical significance, it accords with the findings of earlier intervention studies.

Our analyses further suggest that the reinfarction rate is significantly lower among initial smokers who stop smoking and among initial non-smokers who are treated with timolol after the infarction.

Although assessment of the effect of treatment in separate subgroups should be regarded with caution, our observations suggest that the cessation of smoking enhances the effect to timolol treatment on mortality after acute myocardial infarction and is essential in substantially reducing the reinfarction rate.

We thank Leo Giezendanner for statistical assistance.

\section{References}

1 The Norwegian Multicenter Study Group. Timololinduced reduction in mortality and reinfarction in patients surviving acute myocardial infarction. $N$ Engl $f$ Med 1981; 304: 801-7.

2 Beta-blocker Heart Attack Trial Research Group. A randomized trial of propranolol in patients with acute myocardial infarction. FAMA 1982; 247: 1707-14.

3 Hjalmarson A, Elmfeldt D, Herlitz J, et al. Effect on mortality of metroprolol in acute myocardial infarction. Lancet 1981; ii: 823-7.

4 Lochsen PM, Bjartveit K, Haûknes A, Aaro LE. National Council on Smoking and Health, report on tobacco consumption and smoking habits in Norway. Statens Tobakkskaderåd, Karl Johans gate 21IV, Oslo, Norway, 1982: 16.

5 Wilens SL, Plair CM. Cigarette smoking and arteriosclerosis. Science 1962; 138: 975-7.

6 Doyle JT, Dawber TR, Kannel WB, Kinch SH, Kahn HA. The relationship of cigarette smoking to coronary heart disease; the second report of the combined experience of the Albany NY and Framingham, Mass. studies. JAMA 1964; 190: 108-12.

7 Kannel WB. Cigarette smoking and coronary heart disease. Aren Intem Med 1964; 60: 1103-6.

8 Mulcahy R, Hickey N. Cigarette smoking habits of patients with coronary heart disease. Br Heart $\mathcal{Y}$ 1966; 28: 404-8.

9 Jenkins CD, Rosenman RH, Zyzanski SJ. Cigarette smoking. Its relationship to coronary heart disease and related risk factors in the Western Collaborative Group Study. Circulation 1968; 38: 1140-55.

10 Wilhelmsen L, Wedel H, Tibblin G. Multi-variate analysis of risk factors for coronary heart disease. Circulation 1973; 48: 950-8.

11 Gordon T, Kannel WB, McGee D. Death and coronary attacks in men after giving up cigarette smoking. A report from the Framingham Study. Lancet 1974; ii: 1345-8.
12 Slone D, Shapiro S, Rosenberg L, et al. Relation of cigarette smoking to myocardial infarction in young women. $N$ Engl f Med 1978; 298: 1273-6.

13 Doll R, Peto R. Mortality in relation to smoking: 20 years' observations on male British doctors. Br Med $\mathcal{H}$ 1976; ii: 1525-36.

14 Bain C, Hennekens CH, Rosner B, Speizer FE, Jesse MJ. Cigarette consumption and deaths from coronary heart-disease. Lancet 1978; i: 1087-8.

15 Reid DD, Hamilton PJS, McCartney P, Rose G, Jarrett $\mathrm{RJ}$, Keen $\mathrm{H}$. Smoking and other risk factors for coronary heart-disease in British civil servants. Lancet 1976; ii: 979-84.

16 Rose G, Hamilton PJS. A randomised. controlled trial of the effect on middle-aged men of advice to stop smoking. I Epidemial Community Health 1978; 32: 275-81.

17 Rose G, Hamilton PJS, Colwell L, Shipley MJ. A randomised controlled trial of anti-smoking advice: 10-year results. F Epidemiol Commonity Health 1982; 36: 102-8.

18 Multiple Risk Factor Intervention Trial Research Group. Multiple risk factor intervention trial: risk factor changes and mortality results. FAMA 1982; 248: 1465-77.

19 World Health Organization European Collaborative Group. Multifactorial trial in the prevention of coronary heart disease. 3. Incidence and mortality results. Eur Heart I 1983; 4: 141-7.

20 Hjermann I, Byre KV, Holme I, Leren P. Effect of diet and smoking intervention on the incidence of coronary heart disease. Lancet 1981; ii: 1303-10.

21 Mulcahy R, Hickey N, Graham I, McKenzie G. Factors influencing long-term prognosis in male patients surviving a first coronary attack. Br Heart $\mathcal{F}$ 1975; 37: 158-65.

22 Mulcahy R, Hickey N, Graham IM, MacAirt J. Factors affecting the 5 year survival rate of men following acute coronary heart disease. Am Hean f 1977; 93: 556-9.

23 Martin CA, Thompson PL, Armstrong BK, Hobbs MST, DeKlerk N. Long-term prognosis after recovery from myocardial infarction: a nine year follow-up of the Perth Coronary Register. Circulation 1983; 68: 961-9.

24 Wilhelmsson C, Vedin JA, Elmfeldt D, Tibblin G, Wilhelmsen L. Smoking and myocardial infarction. Lancet 1975; i: 415-20.

25 Salonen JT. Stopping smoking and long-term mortality after acute myocardial infarction. Br Heart $\mathcal{F}$ 1980; 43: 463-9.

26 Hickey N, Mulcahy R, Daly L, Graham I, O’Donoghue S, Kennedy C. Cigar and pipe smoking related to four year survival of coronary patients. Br Heart $\mathcal{F}$ 1983; 49: 423-6.

27 Mulcahy R. Influence of cigarette smoking on morbidity and mortality after myocardial infarction. Br Heart $\mathcal{F}$ 1983; 49: 410-5.

28 Aberg A, Bergstrand R, Johansson S, et al. Cessation of smoking after myocardial infarction. Effects on mortality after 10 years. Br Hean $\mathcal{F}$ 1983; 49: 416-22.

29 Sparrow D, Dawber TR. The influence of cigarette smoking on prognosis after a first myocardial infarction. A report from the Framingham Study. 7 Chronic Dis 1978; 31: 425-32.

30 Daly LE, Mulcahy R, Graham IM, Hickey N. Longterm effect on mortality of stopping smoking after unstable angina and myocardial infarction. Br Med F 1983; 287: 324-6. 